\title{
A PATTERN OF EMPOWERMENT IN IMPROVING THE PROFESSIONALISM OF SCHOOL SUPERVISORS
}

\author{
Akhmad Nirwan \\ Kemendikbud Jakarta. \\ nirwanakhmad@gmail.com
}

\begin{abstract}
This study aims to obtain a pattern of empowerment to improve the professionalism of the school supervisors in Jakarta. This study employed the qualitative approach. The research subjects were school supervisors that consisted of key-informant, school supervisors' colleagues, and coordinators of school supervisor. The data were collected through in-depth interviews, participant observation, and document analysis. The data were analyzed using qualitative data analysis techniques by Creswell Model. This study obtained an empowerment pattern of school supervisors to improve professionalism. There are five elements related to the empowerment pattern of school. First, the empowerment is the effort to develop themselves independently based on competencies and main duty. Second, empowerment is done by the implementation of $\mathrm{CPD}$ which is focused on the goals of empowerment and benefit in the increase of competencies, professionalism, responsibility, initiative, performance, and job satisfaction. Third, the constraints in the empowerment of school supervisor include the lack of facilities provided and low selfmotivation of the school supervisors. Fourth, the solutions to overcome the constraints of the empowerment in improving the professionalism of the school supervisors include improving the commitment of all parties. Fifth, professionalism is defined as a full-time job, competence-based, having a code of ethics, having professional organization, doing their best, and making decision independently.
\end{abstract}

Keywords: empowerment, professionalism, school supervisor

\section{POLA PEMBERDAYAAN DALAM MENINGKATKAN PROFESIONALISME PENGAWAS SEKOLAH}

\author{
Akhmad Nirwan \\ Kemendikbud Jakarta. \\ nirwanakhmad@gmail.com
}

\begin{abstract}
Abstrak
Penelitian ini bertujuan untuk menemukan pola pemberdayaan dalam meningkatkan profesionalisme pengawas sekolah di DKI Jakarta. Penelitian ini menggunakan pendekatan kualitatif dengan jenis fenomenalogis. Subjek penelitian ini adalah pengawas sekolah yang terdiri dari pemberi informasi utama, teman sejawat pengawas sekolah, dan koordinator pengawas sekolah. Data dikumpulkan melalui wawancara mendalam, pengamatan partisipasi, dan dokumentasi. Data dianalisis menggunakan model Creswell. Hasil penelitian ini menemukan pola pemberdayaan pengawas sekolah dalam meningkatkan profesionalisme. Ada lima unsur yang terkait dengan pola pemberdayaan pengawas sekolah. Pertama, pemberdayaan adalah usaha mengembangkan diri secara mandiri sesuai kompetensi dan bidang tugas. Kedua, pemberdayaan dilaksanakan melalui Pengembangan Keprofesian Berkelanjutan (PKB) yang fokus pada tujuan pemberdayaan dan bermanfaat untuk meningkatnya kompetensi, profesionalisme, tanggung jawab, prakarsa, kinerja, dan kepuasan kerja. Ketiga, hambatan pemberdayaan adalah belum adanya fasilitas yang memadai dan rendahnya motivasi pengawas sekolah. Keempat, solusi mengatasi hambatan pemberdayaan dalam meningkatkan profesionalisme pengawas sekolah adalah komitmen bersama semua pihak. Kelima, makna profesionalisme adalah kerja penuh waktu, sesuai kompetensi, punya kode etik, punya organisasi profesi, melakukan yang terbaik, dan membuat putusan mandiri.
\end{abstract}

Kata kunci: pemberdayaan, profesionalisme, pengawas sekolah 


\section{Introduction}

The low quality of education is a problem that has long been faced by the world of education in Indonesia. Many efforts have been done by the Government to improve the quality of education, but have not yet reached the expected results. Based on the report of The Learning Curve Pearson, a world-class education ranking institution released on May 13, 2014, it was reported that Indonesia sit on the last position of the 40 studied countries.

The quality of education in Indonesia is still low, marked by the high levels of unemployment. This indicates that the learning process in schools requires many more efforts, including supervision by school supervisors. Supervisors are required to improve the teachers' professionalism under the coaching to work professionally and wit high quality results. Professional and high quality teachers will also produce high-quality graduates capable of further studies to favorite school or accommodated in the workplace.

The supervisor plays a crucial part in solving the problem of education quality because supervision is like a chain link between teachers and education quality. This is confirmed by Ediger (2002) that the supervisor is the most important factor affecting the quality of education output.

Ediger's opinion supports the Regulation of the State Ministry of Efficient Utilization of State Apparatus and Bureaucratic Reform No. 21 Year 2010 Concerning the Functional Supervisory and Credit Figures mentioned, "The main duties of the supervisor is: to prepare, execute, evaluate the surveillance program, to guide and train professional teachers" (Menteri Negara Pendayagunaan Aparatur Negara dan reformasi Birokrasi, 2010). Furthermore, in Article 1 Paragraph 2 it states, "Supervisors are Civil Servants that are given full duties, responsibilities and authority by the authorities to carry out academic and managerial supervision tasks at schools.

Supervisory position as a profession implies that this position can only be filled by people with expertise or competence in carrying out duties as a supervisor. The supervisor should be able to increase his/her own professionalism before increasing the teachers'. However, the reality on the field shows that the inspectors' professionalism is lower than the teachers they cultivate. Teachers are more skilled at making research actions, unlike the supervisors. Teachers have mastered the implementation of the 2013 Curriculum, unlike their supervisors. This occurs because teachers have more practices, while the supervisors are rarely or even never do.

The lack of professionalism in supervisory is caused by various factors, starting from the systems of recruitment, placement, rotation, coaching, and even to dismissal. All of these factors influence their professionalism as long as the local autonomy is influenced by political factors instead of professionalism. Consequently, there are supervisors who are recruited, placed, transferred and trained due to supporting the Regent/Mayor during local elections (Anonim, 2014, p. 10).

The lack of professionalism can also be seen from the number of supervisors managed to empower themselves with the evidence of promotions and groups. The career development of supervisors are stalled in rank/class IV/a, even though the regulations require supervisors to be promoted every four years. Still, there is no strict sanction from the government about it, as they tend to ignore it. Most supervisors retire in IV/a, because they could not collect the credits required for professional development in the form of scientific papers as one of the requirements to be promoted.

The above facts support article on Kompas online (Napitupulu, 2012) on May 5,2012 , that says that the professionalism of the school supervisor from the primary to secondary education are complained by many parties. This is further compounded by statements from some teachers that the presence of supervisors at schools actually interferes with and hinders the improvement of school quality. This is a chal- 
lenge for supervisors to eliminate the developed negative stigma.

Proof of supervisors' professionalism can be seen from the rank/class they achieve. Of the 23,047 school inspectors in Indonesia, 5,851 are supervisor of secondary education and only $920(16 \%)$ that are able to prove their professionalism by achieving the rank/class of IV/b to IV/e, while the remaining 4,931 (84\%) are still stuck on the IV/a due to inability make up the Contous Professional Development (CPD). (Directorate of Teachers and Education Personnel, the Ministry of Education and Culture for Secondary Education in 2013).

The condition of supervisors of secondary education in DKI Jakarta is not much different. Of the 74 inspectors, only $27(36 \%)$ can attain the rank/class of IV/b to IV/e, while the remaining $47(64 \%)$ are still stuck in the rank/class IV/a due to inability to compose papers on self-development.

Many efforts have been done by the government to improve the motivation and professionalism of the supervisors, in the form of provisioning of various incentives such as transport money for school visits, in addition to performance benefits and salaries as Civil Servants and professional allowances from the central government. All aimed to improve their motivation and professionalism, yet have so far been for naught.

It has been thought that the root problem is because the supervisors have not yet empowered themselves effectively. To increase the professionalism of supervisors, Sagnak, (2012) suggested them to empower themselves.

Empowerment is an increase in intrinsic motivation independently (Thomas \& Velthouse, 1990; Kabeer, 2001; Robbins, Odendaal, \& Roodt, 2003; Alsop, Bertelsen, \& Holland, 2006, p. 10; Gill, 2006; Yukl, 2010).

The focus of this research is empowering school supervisors in DKI Jakarta. The formula of the research is "What is the pattern of empowerment required to im- prove the professionalism of inspectors?" This formula is translated into the following research questions: (1) the meaning of empowerment for supervisor, (2) the implementation, objectives and benefits of empowerment for supervisor, (3) the inhibitors towards empowerment for supervisor, (4) the solution to overcome the obstacles of that empowerment, (5) the meaning of professionalism according to the supervisor?

The research objective is to find the pattern of empowerment in order to improve the professionalism of supervisors. The pattern in question is the recurring behaviors that often appear in enhancing professionalism in the effort to empower themselves in their daily work activities.

\section{Research Method}

This study uses a qualitative approach with a phenomenological type. This type of research is chosen because the researcher wants to get the meaning behind the data of empowering school inspectors collected in the field Creswell (2014). Furthermore, the researcher found a pattern of empowerment in improving the professionalism of supervisors based on the meaning of behaviors that often arise in the field.

The focused research setting is the secondary education office in DKI Jakarta. The reasons for this location for research are: (1) DKI Jakarta has unique characteristics as a special area and can be used as a pilot case to uncover the empowerment of supervisors; (2) The supervisors in Jakarta have gotten more incentive compared to those in other areas, so it is assumed that (3) supervisors of the secondary education in DKI Jakarta have been able to empower themselves, as found by the researcher in the preliminary study; (4) the quality of the secondary education in DKI Jakarta has increased quite significantly from year to year. This increase cannot be separated from the contribution of all concerned parties, especially the role of supervisors as a builder component. 
The subject of research is the supervisors of the secondary education that have been able to prove their professionalism. They were chosen as key informant because: (1) the relationship of the researcher with them is not too close but not too far either; (2) the relationship of the researcher with them has so far been only in the workplace; such as by inviting them as a resource in various program activities related to teachers, principals, and supervisors; (3) this kind of relationship is considered as adequate to meet the requirements for qualitative research so that the obtained data and information are guaranteed for objectivity; (4) they are diligent to empower themselves with the proof of achievements that they earned; (5) they are such figures that help colleagues to develop their self-competence through the 'Working Group of Supervisors (MKPS) and the Association of Indonesian School Supervisors (ASPI);

Data collection techniques being used are (1) depth-interview, (2) observation, (3) documentation, (4) audio and visual material. The research instrument is the researcher (human instrument). The collected data refers to the research questions.

The type of data collected is qualitative in the form of descriptive words, but also accepts the possibility for numeric data to support the qualitative data. Data in this study relates to empowerment to increase the professionalism of supervisors.

The results of in-depth interviews with key informant. At first, the researcher makes an agreement regarding the time, place, and purpose of the interview. Once it is settled, the researcher begins the interviews, conducted in various informal atmosphere and places.

The interviews are general at first and then lead to be more specific and deeper. The researcher must try to be a good listener while taking notes and record the answers. Before recording, researcher must first ask for permission. Records made during the research is called field note. Each data obtained from one informant must be cross-checked with another informant to gain a relatively objective data. Subject continues to grow like a snowball, coupled with six inspectors so the obtained data is saturated (redundancy), which mean that the data can no longer change. Thus, there the sources of data are nine people.

During the study, researcher tries to keep a distance with the nine data sources, so that the association relationship between them is not too far and not too close, to ensure the objectivity of obtained data and information. This research is conducted in 11 months, from July 2014 to May 2015.

To conduct participatory observation, researcher must be present in the moments when the key informants empower themselves, such as when they are creating training guide, making training material, providing materials in training, assess the principals and teachers that have achieved national level, providing materials at scientific meetings. Observation data is recorded and photographed by researcher as carefully and completely as possible.

Results from the key informant interviews are then checked by using the documentation techniques conducted by researcher by collecting physical evidence in printed, recorded, and noted that support the results from interviews and observations, in order to get data that can be accounted for.

The validity of data obtained in this study is gained by fulfilling the factors of credibility, transferability, dependability, and confirmation. The methods are as follow:

Credibility of the data gained in the field can be confirmed by the following methods: (1) extend the observation period from July 2014 to May2015; (2) careful observations; (3) triangulation with other sources of information and compare interview results with observations and documentations; (4) discuss with others (peer debriefing), which is with other researchers in the Graduate Program of Yogyakarta State University on various occasions; (5) use reference materials such as books that are relevant to data and research questions; 
(6) member checks by examining the results of the data obtained with the nine data sources.

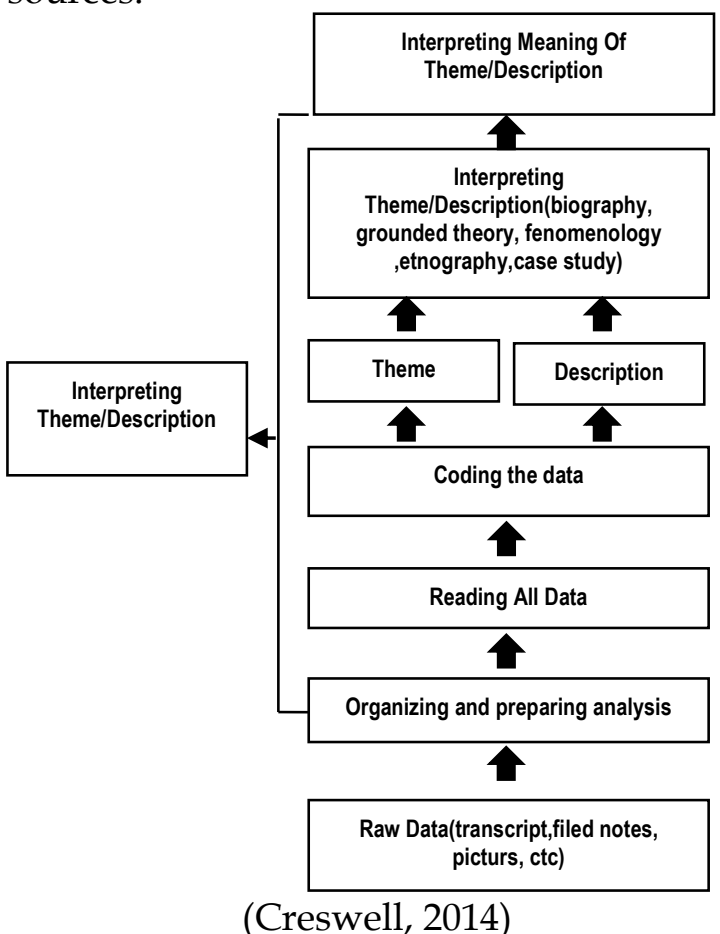

Figure 1. Research Data Analysis

Transferability occurs if the results of supervisors empowerment in DKI Jakarta can be applied to supervisors in other places. Transferability that depends on characteristics of the location of research results can be applied and will only happen if the characteristics of the place to apply the results of research are relatively the same or nearly the same as the place of this research.

Dependability is when the results of the study yield the same results with studies of other party. For a qualitative research to meet dependability requirement, it would need to be combined with confirmation. This is done through an audit trail (trace back) by the supervisors, which are the promoter, co-promoter, and members of the dissertation testers. These supervisors are entitled to check the correctness of data and interpretation.

Confirmation relates to the objectivity of research. To fulfill this, the audit trail needs to be done by inspection to ensure that the reported results are truly what they are, with nothing added or subtracted.
Researcher conducts the study repeatedly against any data obtained. Researcher strives to ensure the certainty of data obtained by conducting repeated interviews, confirming with other sources, re-examining the record of existing data, and reviewing documents obtained many times over. All of these are done solely to ensure the certainty of the data obtained.

Data analysis in this research is using the Creswell model as depicted in the Figure 1.

\section{Research Result and Discussion}

Research Result

Meaning of Empowerment for School Supervisor

Based on the result of depth-interviews with the key informant in this study so that the data becomes redundancy, and the result can be concluded that empowerment meaning in the perception of school supervisor is the effort to increase competences based on their task which has done independently in accordance with the opportunity to improve appraisal

Furthermore, the results of interviews with research key informants was triangulated to other sources of information so that data becomes redundancy. The results of the triangulation process with all informants in substance turned out similar in interpreting the empowerment of supervisors, the differences are editorial only.

The result of observations, the researcher see for himself the evidence of empowerment of the data conducted by key informants as diligently followed the invitation as a resource in the training activities carried out by Ministry of Education and Culture, made a training guide, preparing training materials, preparing supervisory workbook, being a resource person supervisory training, become a supervisor assessment team achievement, writing textbooks, school conduct action research, fostering an increase in the professionalism of teachers, building principals capacity, building the capacity of other 
education personnel at schools (school administrative staff, school library staff, and laboratory assistant)

Implementation, Objectives and Benefits of Empowerment for Supervisors

Based on interviews with key informants in this study concluded that the implementation of empowerment is done through CPD which consists of the improvement of academic qualifications, to produce scientific papers, actively participating in seminars and training, and joining professional organizations. The main goal of empowerment is to improve the professionalism of supervisors. Benefits of empowerment is the increasing competence, professionalism; responsibility; initiatives in the works; performance and job satisfaction.

Next step, the results of interviews with key informants of this research was triangulated about the data sources to colleagues and supervisors coordinator so that data becomes redundancy. The triangulation result turns out that all confirmed the key informants' opinion on the implementation, objectives, and benefits of empowerment. All key informants come to the same perception about implementation, objectives, and benefits of supervisor empowerment, the differences are editorial only.

Observations on the implementation, objectives, and benefits of empowerment, the researcher proved by himself in the form of key informants implement empowerment that he empowers himself by doing CPD, achieve the goal of professionalism among others, he works independently without being told, most of the time he uses to work as a supervisor, only works according to the field and he refused which is not on his field, actively participate in professional organizations and adhere to a code of ethics.

Results documentation concerning the implementation of empowerment has been achieved, among others, a number of key informant scientific papers, textbooks, certified as a resource in the various seminars/workshops, and certification as member of the supervisory assessment team at the national level. Interviews, document studies and observations conducted by the researcher of the implementation, purpose and benefits of empowerment for school supervisors found something more related to the effort done independently. School supervisor's effort in empowering themselves by improving the competence through increasing academic qualifications, actively writing scientific papers, being active in various seminars and training, and being active in professional organizations with the aims to improve the professionalism of themselves. All aims mean to improve the professionalism of supervisors and have an impact on improving the competence, responsibility, initiative in the work, performance, and job satisfaction.

The Constraints of Empowerment of Supervisor

The research results based on interviews with key informants can be concluded that the perceived barriers in an effort to empower school supervisors is low motivation, overloaded work and lack of facilities provided advisory institution.

Furthermore, the data of the depth interviews with the key informant was triangulated to a colleague and a coordinator supervisor so that data becomes redundancy. The triangulation result turns out that both of them confirmed the key informant's opinion about constraints of the empowerment of supervisors. All of the informants in substance stated the same ideas about the constraints of empowerment of supervisors but they delivered their ideas in different ways.

The next step was the observations conducted by the researcher associated with the empowerment barriers experienced by key informant. The researcher proved by himself and follow the key informant spread out his ideas to members of organization of profession. Turns out it was true the obstacle is the absence of a permanent forum for the meeting of the working group.

Interviews, document studies and observations made finding some obstacles 
perceived by supervisors. Perceived barriers in an effort to empower supervisors is low self-motivation, overloaded work and lack of facilities provided by advisory institution. Based on the data obtained it can be concluded that the difficulties faced by supervisors in empowering themselves are low self-motivation and a lack of supporting facilities provided by advisory institution.

The Solutions to Overcome the Constraints of the Empowerment of Supervisor

Based on interviews with key informants in this study concluded that the solutions to overcome the barriers to empowerment in improving the professionalism of the school supervisor is the common commitment of all parties about the importance of the task of school supervisor.

Furthermore, the interviews data got from the key informant in this study was triangulated to a colleague and a coordinator supervisor so that data becomes redundancy. The result of the data based on the triangulation process justify the key informant's opinion about solutions to overcome barriers related to the empowerment of supervisors. All of the key informants come to the same ideas in solutions to overcome barriers of supervisor empowerment but they stated them in different statement only.

There will be a way out to any obstacle that is faced by supervisors in empowering themselves. Interviews, document studies and observations conducted by the researcher discovered things which were done by supervisors to overcome these obstacles and possible solutions that may be carried out either by the school supervisor themselves or by an advisory institution. Solutions to overcome barriers to empowerment (1) increase self-motivation (2) the provision of facilities for school supervisor to develop themselves (3) implement regulations correctly in the form of reward and punishment (4) make rules about the use of the professional allowance funds received by supervisors.
The researcher observed the key informant in the solution for overcoming the obstacles of empowerment. The result proved that the key informant has successfully overcome barriers in empowering himself indicated by the success of achieving remarkable achievements. The researcher observed morale high key informant. Key informant quite creative in doing coaching programs for example by showing his works to teachers and principals under his guidance.

Professionalism Meanings According to the Supervisor

Based on interviews with key informants can be concluded that the meaning of professionalism is: full-time work, working in accordance with the competence, has a code of ethics, has a professional organization; do the best; and make decisions independently.

Furthermore, the data got from the interviews with the key informants was triangulated to a colleague and a coordinator supervisor so that the data is redundancy. The triangulation result turns out that both of them confirmed the key informant's opinion about the meaning of professionalism. All of them have similarities in substance in giving the meaning of professionalism but different editorial only

\section{Discussion}

\section{Meaning of Empowerment for Supervisors}

Based on the results of research conducted on key informant found that the meaning of the empowerment of supervisors is an attempt to increase the competence in accordance with the tasks carried out independently by utilizing the opportunity to come to improve performance.

The study found that the empowerment of supervisors conducted independently in accordance with the opportunity obtained to improve the performance indicate that an independent person will be aroused his intrinsic motivation if he is able to read and take advantage of opportunities or given a chance by the other 
party. The assumption is intrinsic motivation that exists in every human being will arise or increase if they receive the stimulation of extrinsic motivation.

Empowerment through the provision of opportunities to the supervisor found that supports the theory of stimulus-response which is well known from Skinner that every action will cause a reaction. Humans were given the opportunity means humans need to be given the experience. These findings support the experimentalism philosophical idea which has understood that humans are influenced by the environment. Supervisors will be increasingly more powerful if the environment provides the opportunity for it.

All key informants understand that because they feel the quality and the achievement are the matter of self-reliance. Therefore, they do all their own activities that create competence increased especially related to supervisory tasks. Principles that are embedded in supervisors' mind are to always equip themselves with various activities proved fruitless and can be role models for other supervisors although they were carried out at their own expense and without any coercion from outsiders. Consciousness as a supervisor who must build the capacity of the school community that are under their responsibility have increased high self-motivation to constantly knowledge through a variety of occasions.

Findings in self empowering is supporting educational goals expressed by our educational leaders, Dewantara (1960) which states that education is a matter how to make human being independently. The meaning contained in the expression of $\mathrm{Ki}$ Hadjar Dewantara is the higher one's education, the higher the independence. The example of independence of educational outcomes that do not rely on others to make decisions, solve problems, overcome difficulties, and maintain personal safety.

Results of this study turned out to support the Y theory of McGregor (1961) which states that human beings have a Ytype characteristics: (1) be independent, (2) work with full consciousness without having to be supervised, (3) be responsible, and (4) want to lead. The findings of this study support the Yogyakarta State University's vision that is to produce graduates who are devout, intelligent and independent.

Independence that has been conducted by key informant like; improving education qualifications independently, create and print books, seminars and workshops they do because they want to gain external recognition called self-actualization. Key informants wanted to meet the five levels of Maslow's hierarchy of needs that is selfactualization.

Results of this study turned out to support the research done by Lo, Zhao, Liu, \& Coping (2008) which states empowerment is their extrinsic motivation. Results of the study found that empowerment is an attempt to increase the competence in accordance with the tasks carried out based on the opportunity to come to improve performance. Opportunity is extrinsic motivation.

Results of this study supports the notion of Yukl (2010) which states that empowerment is an effort how intrinsic motivation run. This support occurs because both the school supervisor and Yukl alike interpret the empowerment comes from someone intrinsic motivation to develop themselves independently.

Results of this study turns out the support to the notion of Whitehead, Boschee, \& Decker (2004) which states that an effective leader is a leader who is able to empower their subordinates effectively. This support occurs because the leader who is able to empower their subordinates effectively is gained an opportunity to improve performance according to these research results.

Implementation, objectives and benefits of Empowerment for Supervisors Based on the results of research conducted on key informants was found that the implementation of empowerment made through CPD which among others include: increase educational qualifications; produce scientific papers; actively participate in seminars 
and training; join a professional organization. Empowerment goal is to improve professionalism. Benefits of empowerment is the increasing of the competence, professionalism; responsibility; initiatives in the works; performance and job satisfaction. All of the key informants had relatively similar answers about the implementation, objectives, and benefits of empowerment due to the similarity background.

Results of this study turned out to support the opinion of Manning \& Curtis (2005, p. 133) which states that the goal of empowerment is to improve performance. The findings of this study also support the findings of the study of Randolph \& Blanchard (2007) who found that people who are empowered will benefit the organization as a whole.

Results of this study support the notion of Alsop et al. (2006, p. 10) which states the purpose of the empowerment is to make an effective choice. The results also support the notion of Yukl (2010) which states the benefits of empowerment is to increase the initiative, responsibility, and satisfaction in work. Benefits of empowerment is to increase the initiative, responsibility, and satisfaction in work is increasing competence, professionalism; responsible; initiatives in the works; performance and job satisfaction according to results of this study.

Benefits of empowerment can enhance the competence for supervisors, when conducting empowerment supervisor received additional competencies (knowledge, experience being, and acting experience). Benefits of empowerment can improve the professionalism as the school supervisor when doing empowering will change attitude that adopts as a professional and become a professional supervisor. Benefits of empowerment can increase the responsibility for the school supervisor when empower got an extra to carry out their duties with full responsibility. School supervisor is aware that responsibility cannot be delegated.

Benefits of empowerment can enhance initiatives because empowerment according to them is an attempt to develop themselves independently. Independent person usually full of initiative because het does not depend on others. Benefits of empowerment can improve the performance of the school supervisor when they do empowerment it will increase their competence.

\section{The Obstacle of Empowerment of Supervisor}

Based on the results of the research conducted on key informant found that obstacles of perceived supervisor in empowerment are low self-motivation, too muck work, and lack of facilities provided by advisory institution. All informants have relatively the same answer about the obstacles of empowerment but they expressed it in diffrent way.

The findings of the research on the obstacles to empowerment support Murphy's law (Anonim, 1990) which states that there will be obstacles in every human being's act. The result of interviews and observations conducted on key informant in this study found the obstacles in implementing the empowerment of supervisors. One of the main barriers found in this study is the lack of adequate facilities for the organization.

Key informant gives the answer like that because supervisors do not have a specific room if they want to hold a meeting. In addition, the school supervisor also noted the number of partner schools make their time and energy drained away just to complete the daily tasks. The impact of that can reduce motivation in doing self-development. Supervisor also said the reward and punishment on the work and achievements of their supervisory work has not been executed by the firm.

Organization facilities is a mean of the organization to perform activities (Usman, 2013). Human being cannot be separated from space and time when doing their activities. Space is the place to do activities. Specific facility is needed like a meeting room to hold a coordination for the organization, and carry out self-development activities. 
Other obstacles in implementing empowerment from school supervisor is low intrinsic motivation to empower himself. Basically, intrinsic and extrinsic motivation are two things that cannot be separated. Both affect each other in practice.

The low intrinsic motivation occurs because of some reasons such as: the time and energy that largely exhausted to perform daily task as supervisor, no sanctions for supervisors that cannot be promoted every four years, the supervisor works independently unattended, the report was not followed up by the local government advisor, supervisor is passively empowered by the government (wait for extrinsic motivation), have difficulties in making paper, and do not receive training opportunities.

The main purpose of the government provides various incentives is to increase both intrinsic and extrinsic motivation of supervisor. However, various types of incentives have not automatically link to the increase of the professionalism of supervisors. In fact the amount of incentives received by the supervisor has not yet motivated all supervisors to empower themselves. Supervisor requires a form of reward rather than just in the form of welfare in financial terms. They expect that the supervisory report they have arrange will be one of the consideration in formulating education programs.

Various types of incentives received by the supervisor have not yet motivated the supervisor to empower themselves. It supports White's theory that states the money does not guarantee work motivation increased because humans have a saturation point.

Solutions to Overcome the Constraints of the Empowerment of Supervisor

Based on the results of the research conducted on key informants found that solutions to overcome the obstacles to empowerment in improving the professionalism of the school supervisor is the common commitment of all parties about the importance of the task of school supervisors.
All the key informants had relatively similar answers about the solutions to overcome the obstacles because all of them have similar background.

Bureaucratic system that has been applied in Indonesia for long time have created such people who always or prefer to wait being assigned rather than doing its own innovations and creations. Innovations in making decisions, especially related to the field of supervisor duties was still lack that disrupts the performance of the supervisor itself.

For supervisors who are able to develop themselves without waiting for directives or orders from superiors will perform much better than those who just always await. Consequently, those who do not have high self-motivation to improve competence in their respective sectors will have difficulty developing innovation and creativity that will ultimately have an impact on the performance and professionalism of the school supervisor itself.

Reward and punishment is not applied as it should is another constraint on the empowerment of school supervisors. Some school supervisor still think that they do not need to achieve excellent performance because it is not a big influence on their careers as supervisors. Supervisors performance appraisal also does not apply and it causes another reason to lower selfmotivation for supervisors in developing their competence.

The workload is very much perceived as well as the obstacles to self-empowerment. Time school supervisor is largely consumed to perform supervisory tasks demotivating them to improve their competence. The absence of clear guidance program from the regulatory agency resigned to the existing situation.

The results of interviews with the three informants can be used as an alternative solution to solve the problems facing supervisors to empower themselves. All of them say that it needs the strong commitment from the advisory institution. The three of them answered that way because they offer solutions to overcome the 
barriers to empowerment in improving the professionalism of the supervisors is a joint commitment of all parties how importance of supervisor tasks. This commitment does not build not in rhetoric only but also more important is the implementation. Supervisors always need to build self-motivated to develop. This motivation is needed by all school supervisors if they want to have pride as a supervisor.

Pride as a supervisor can be felt if the supervisor gets sympathy from the schools under his guidance. All school community will always miss them. For that purpose, the supervisor must equip himself with the knowledge, attitudes, and skills needed in doing his work as supervisor at schools. Intrinsic motivation to be a better supervisor is required in this regard.

Solutions to overcome the barriers to the empowerment associated with the lack of facilities is driving organizations to negotiate to borrow the school hall. In the medium term, to propose to the government to provide a space for supervisor organization (MKPS) . For the long term, to propose to the government to construct the building for them. Solutions to overcome all the barriers above can be done by: awareness, training, organizing, development strength, and build dynamic.

Yukl (2010) stated that efforts to improve employee empowerment more often implementing programs of organizations rather than individual. Empowerment program that can be used to increase the empowerment are: (1) the team of managing himself, (2) processes and democratic structures, and (3) employee ownership of the institution. Moreover, Yukl (2010) said that there are three organizational empowerment program, namely: (1) assessment and selection of leaders, (2) democratic decision procedure, and (3) share the responsibilities of leadership.

Blanchard (2009) provides three keys of empowerment in solutions to overcome the barriers to empowerment, namely: (1) share information with any person, (2) creating autonomy, (3) replacing the old hierarchy by giving direct orders indivi- dually and team. In line with Blanchard, Yukl (2010) stated that the actions of leaders and decision-making process is an important factor that determines empowerment.

\section{Professionalism Meaning in Supervisor's Opinion}

Based on the results of research conducted on all the key informants was found that the meaning of professionalism are: full-time work, work based on the competence, has a code of ethics, have a professional organization; do the best; and make decision independently. All the key informants had relatively similar answers about the meaning of professionalism because of their similar background of knowledge and experience.

Interview results with of all the key informants found the meaning of professionalism that is the one who has the knowledge, attitude and competence as a supervisor, is working full time job to earn a living, is appropriate background expertise. Supervisor who was the subject of this study agrees and argues that professionalism is something that is related to skill and background knowledge of a person.

All key informants say that because supervisor as a profession should be given to those who have knowledge and skills in the field of education. Supervisors must devote all their energy and mind to achieve maximum results in performing supervisory tasks. Being a supervisors should be run as a full-time job not part time or amateurs.

The findings of this study turned out to support the research Murwaningsih (2007) which concluded that the major determinant factor determining the success of improving the quality of education is the professionalism of teachers. Professionalism of teachers needs to be improved through qualification, competencies, depth of knowledge, and remuneration for their welfare. Professional teachers are required to always increase professionalism on an ongoing basis. This research support for research Mufathonah (2006) as studied 
were equally teachers. School supervisor is a professional teacher.

The findings of this study turned out to support the views expressed by Tangkilisan (2005) which states that professionalism requires specific knowledge and skills through education and training.

Results of this study support the notion of Danim (2002) which states that professionalism is a commitment to a profession to improve their professional ability and constantly develop strategies used in doing the work in accordance with the profession. Professional development goal is to meet three requirements: (1) social needs that enhance the ability of the education system efficiently and adapted for the preparation of social needs, (2) the need to find ways to help education staff in order to develop his personal widely; (3) the need to develop and encourage personal life such as helping teachers to develop personal desires and demands based on their potential (Danim, 2002).

The findings of this study support the notion of Danim (2002) which states professionalism is a member of a profession's commitment to enhance the professional skills and constantly develop strategies used in doing the work in accordance with their profession. Furthermore, Danim states that professional development is doing to meet three requirements: (1) social needs, (2) the need to find ways to help education staff, and (3) the need to develop a personal life. The findings of this study support the notion of Satori (2010) which states that the professionalism refers to a member of the profession's commitment to enhance the professional skills continuously.

Based on quantitative data from 200 school supervisors who completed a questionnaire about the pattern of empowerment in improving professionalism as supportive data to the results of this study can be explained school supervisor turned out $85 \%$ agree with the points listed in the questionnaire. These supporting data do not intend to generalize the results of this research for school supervisors throughout Indonesia but merely reinforces the re- search findings because the study uses a phenomenological approach which means to look for the meaning behind the data.

\section{Conclusions}

The meaning of empowerment is the effort to increase competence in accordance with field task which is done independently, based on the opportunity gained to increase the performance. The meanings embodied in this data are: (1) empowerment is individual in nature; (2) supervisors do not hope too much to be empowered by the government; (3) superiors trust the supervisors to autonomously empower themselves; (4) supervisors should motivate themselves to do CPD; (5) supervisors set aside some of the incentive to empower themselves; (6) supervisors should be dynamic; (7) empowerment is a multidimensional concept; (8) empowerment demands changing in behavior; (9) supervisors should change their own fate, do not wait to be changed by others; (10) meet the philosophy of science of axiology empowerment.

The implementation of empowerment is done through CPD which covers: the improvement of educational qualification; generate scientific papers; actively participated in seminars and workshops; affiliate in a professional organization. The purpose of empowerment is to increase professionalism. The meaningful goals of empowerment are: (1) every activity must have clear purpose; (2) give direction to member of organization to implement empowerment; (3) match the mind set, pattern, and attitude to reach the goal; (4) motivate each member of organization to achieve the goal; (5) to perform mission, (6) consist of short, medium and long term; dan (7) can be translated into goals. The benefits of empowerment are to increase competence, professionalism, responsibility; initiatives in the works; performance and work satisfaction.

The meaning of empowerment benefits are (1) the theoretical benefits, which contribute to the theory of the benefits of 
empowerment; (2) The practical benefits, which means benefits of empowerment to improve: competence, professionalism, responsibility, initiative, performance, and job satisfaction; (3) without benefits, all works will be in vain; (4) comply with the principle of benefit in any decision making; (5) give encouragement to obtain those benefits; (6) to satisfy the philosophical science of empowerment axiology.

The barriers perceived by supervisors in empowerment efforts are: the low intrinsic motivation, too many workloads, and lack of containers provided by advisory institution. This means: (1) for every action there's always a blocking barrier; (2) the supporting performance facilities of school supervisors have not yet became a priority of the advisory institution to provide; (3) money is not a problem for school supervisor because incentives is relatively adequate. The low work ethics of the supervisors is caused by: (1) the low awareness to improve oneself; (2) lack of extrinsic motivation from the superiors of school supervisors; (3) lack of motivation towards achievements; (4) the supervisors already feel satisfied with what they have; (5) the school supervisors feel helpless with their fate; (6) they have no will to change their fate; (7) there is no sanction for the supervisor who fails to go up in rank every four years; (8) lack of competence to fulfill the requirements to go up in rank.

The solution to solve this empowerment problems are through commitment from all related parties regarding the significance of the supervisors' tasks. This means: (1) the needs to enhance intrinsic motivations of the supervisors; (2) provide facilities to empower the supervisors; (3) apply rules and regulations strictly; (4) create the rules and regulations of allowance usages for self-empowerment; (5) create innovative creations to handle heavy workloads.

The meaning of professionalism are: to work full time, work in accordance with competency, to have ethic codes, to have professional organization; to do the best; and making independent decisions.
The pattern of empowerment in improving the professionalism of school supervisors described in Figure 2 below.

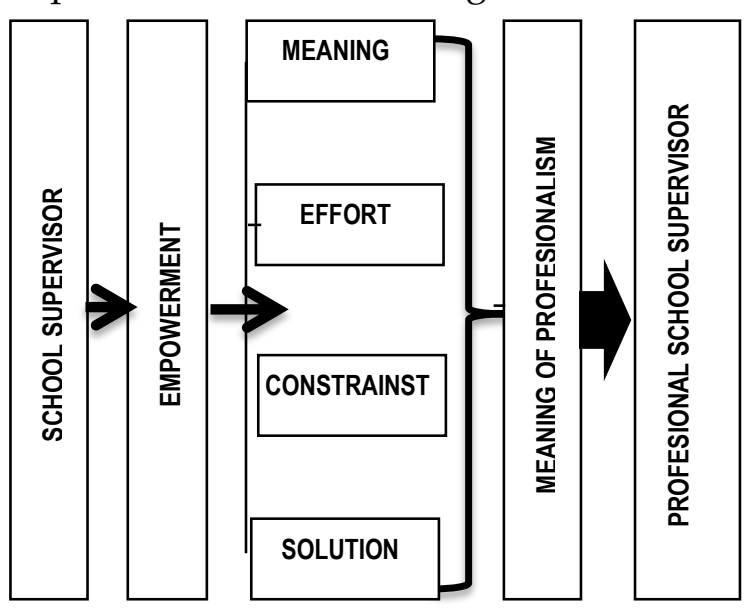

Figure 2. The Pattern of Empowerment in Improving the Professionalism of School Supervisor

The recommmendations refer to the results and benefits of research as follows. Fisrt, for the scientist in the field of Education Management suggested: (a) this study should be followed by subsequent researchers held a public hearing, revising, and piloting so that the model can be accepted as a practical model of empowerment in improving the professionalism of the school supervisor throughout Indonesia; (b) the result of this study should be developed by the next researcher with the approach of Research \& Development (Research \& Development) or use a quantitative approach; (c) the result of this study should be able to proceed by the next researcher to determine the level of effectiveness and efficiency of the implementation of the empowerment of school supervisors.

Second, for Agencies Trustees of School Supervisors: (a) the pattern of empowerment in improving the professionalism of supervisors should be an input for the school supervisor advisory body in empowering supervisors to achieve a more optimal supervisory work which leads to a better quality of education; (b) the empowerment pattern in improving the professionalism of school supervisors should be 
input for an advisory institution to empower them in achieving impressive results more optimal working and lead to a better quality of education; (c) pattern of empowerment in improving the professionalism of supervisor should be considered in preparing the school supervisor competency development program; (d) school supervisors should be empowered through the implementation of regulations by using a system of reward and punishment; (e) supervisors should be encouraged to make use of most of the incentives they received to carry out independent CPD; (f) supervisors should be facilitated in doing CPD and running professional organizations; (g) the report that was designed by supervisor should be promptly followed up and used as a reference policy and program development of quality education; (h) propose to the relevant institution to restructure or merged the profession of supervisor because many regulations are colliding.

Third, for the School Supervisor: (a) supervisors should motivate and professionalize themselves without waiting be empowered by others; (b) supervisors should empower themselves through various means and opportunities provided; (c) supervisors should be able to be a model of good teaching for teachers who are under the guiding; (d) supervisor's papers shold be motivated others doing the same; (e) supervisors should take advantage of its power so that the teacher is able to teach in the best way and at the end will improve the quality of teaching and student learning outcomes; (g) supervisors should obey the rules that they must be promoted every four years; (h) supervisors should set aside some allowances for carrying out their CPD independently.

\section{References}

Alsop, R., Bertelsen, M., \& Holland, J. (2006). Empowerment in practice: From analisysis to implementation. Washinton DC: World Bank.

Anonim. (2014). Kompetensi akademik pengawas sekolah rendah. Kompas.
Blanchard, K. (Ed.). (2009). Leading at a higher level. Upper Saddle River, New Jersey: Pearson Prentice Hall.

Creswell, J. W. (2014). Educational research planning, conducting, and evaluating quantitative and qualitative research (3rd ed.). Upper Saddle River, New Jersey: Pearson Education.

Danim, S. (2002). Inovasi pendidikan dalam upaya peningkatan profesionalisme tenaga kependidikan. Bandung: Pustaka Setia.

Ediger, M. (2002). The supervisor of the school. Education, 122(3, Spring), ProQuest pg 62.

Gill, R. (2006). Theory and practice of leadership. London: Sage.

Kabeer, N. (2001). Reflections on the measurement of women's empowerment in discussing women empowerment: theory and practice. Sida Studies Journal, 3, 29-40.

Lo, S. M., Zhao, C. M., Liu, M., \& Coping, A. (2008). A simulation model for studying the implementation of performance-based fire safety design in buildings. Automation in Construction, 17(7), 852-863. https:/ / doi.org/10.1016/j.autcon.2008 .02 .014

Manning, G., \& Curtis, K. (2005). The art of leadership. Boston: McGraw-Hill Higher Education.

Menteri Negara Pendayagunaan Aparatur Negara dan reformasi Birokrasi. Peraturan Menteri Negara Pendayagunaan Aparatur Negara dan reformasi Birokrasi Nomor 21 Tahun 2010 tentang jabatan fungsional pengawas sekolah dan angka kreditnya (2010).

Mufathonah. (2006). Analisis pengembangan profesionalisme guru pada lembaga pendidikan islam di kota Malang. Malang: Program Pascasarjana Universitas Muhammdiyah Malang.

Murwaningsih, T. (2007). Guru profesional 
dan mutu pendidikan. Yogyakarta: Pusat Penelitian Pendidikan Dasar dan Menengah Lembaga Penelitian Universitas Negeri Yogyakarta.

Napitupulu, E. L. (2012). Kinerja pengawas sekolah dikeluhkan. Kompas. Retrieved from http://edukasi.kompas.com/read/20 12/05/05/13370282/Kinerja.Pengawa s.Sekolah.Dikeluhkan

Randolph, A., \& Blanchard, K. (2007). Empowerment is the key. In $\mathrm{K}$. Blanchard (Ed.), Leading at a higher level. Upper Saddle River, New Jersey: Pearson Prentice Hall.

Robbins, S. P., Odendaal, A., \& Roodt, G. (2003). Organizational behaviour: global and southern african perspectives. Cape Town: Pearson Education South Africa.

Sagnak, M. (2012). The empowering leadership and teachers' innovative behavior: The mediating role of innovation climate. African Journal of Business Management, 6(4). https:// doi.org/10.5897/AJBM11.216 2
Satori, D. (2010). Supervisi akademik dan penjaminan mutu, dalam Konsep dasar ilmu administrasi pendidikan. Bandung: Program Studi Administrasi Pendidikan Universitas Pendidikan Indonesia.

Tangkilisan, H. N. S. (2005). Manajemen publik. Jakarta: Gramedia Widia Sarana Indonesia.

Thomas, K. W., \& Velthouse, B. A. (1990). Cognitive elements of empowerment: an "interpretive" model of intrinsic task motivation. Academy of Management Review, 15(4), 666-681. https:/ / doi.org/10.5465/AMR.1990.4 310926

Usman, H. (2013). Manajeman: teori, praktik, dan riset pendidikan (4th ed.). Jakarta: PT Bumi Aksara.

Whitehead, B. M., Boschee, F. A., \& Decker, R. H. (2004). The principal leadership for a global society. London: Sage.

Yukl, G. (2010). Leadership in organization (7th ed.). Upper Saddle River, New Jersey: Pearson. 